\title{
AMDAL SEBAGAI INSTRUMEN DALAM MEMPERTAHANKAN SUSTAINABLE DEVELOPMENT YANG BERWAWASAN LINGKUNGAN
}

\author{
Oleh : \\ Indah Sari \\ Dosen Tetap Fakultas Hukum Universitas Dirgantara Marsekal Suryadarma dan \\ aktif di LKBH FH Universitas Dirgantara Marsekal Suryadarma serta Anggota Asosiasi Dosen Indonesia (ADI) \\ Email : (Indah.alrif@gmail.com)
}

\begin{abstract}
:
This writing intends to explain what is $A M D A L$, what is its function and also its aim. It is also explain here about the role of $A M D A L$ as an instrument to implement sustainable development policy with its environmental orientation. The crucial role of $A M D A L$ is to keep developmental improvement proceed to sustainable development principles. State need to make a good developmental plan in which it is easier for societies and also governmental institutions to predict its significant impact after the plan being implemented. Developmental processes eventually need to based on AMDAL in considering sustainability of our generation and also next generation life. It is all stated in Act No 32 Year 2009 of Protection and Management of Environment and also in Governmental Regulation No 27 Year 1999 of Environmental Impact Analysis.
\end{abstract}

Keywords: AMDAL, Sustainable Development, Environment, Act No 32 Year 2009

\begin{abstract}
Abstrak :
Dunia usaha saat ini mengalami perkembangan yang sangat pesat. Dalam menjalankan Tulisan ini ingin menjelaskan apa itu AMDAL serta bagaimana fungsi dan tujuan AMDAL. Selanjutnya membahas sejauhmana peranan AMDAl sebagai salah satu intrumen dalam mempertahankan Pembangunan Berkelanjutan yang berwawasan lingkungan. Peranan AMDAL terzebut adalah menjaga agar proses pembangunan berjalan sesuai dengan prinsipprinsip pembangunan yang berkelanjutan. Bahwa pembangunan harus direncanakan secara matang sehingga dapat memberikan prediksi kepada masyarakat dan pemerintah mengenai dampak besar dan penting yang terjadi kedepannya setelah usaha, kegiatan dan pembangunan tersebut dijalankan. Pada akhirnya proses pembangunan yang berdasarkan AMDAL benarbenar harus memikirkan keberlangsungan hidup generasi sekarang dan generasi yang akan datang. Tentu ini harus sesuai dengan peraturan yang berlaku yaitu Undang-Undang Nomor 32 Tahun 2009 tentang Perlindungan dan Pengelolaan Lingkungan Hidup dan Peraturan Pemerintah Nomor 27 Tahun 1999 Tentang Analisis Mengenai Dampak Lingkungan (AMDAL).
\end{abstract}

Kata kunci: AMDAL, Pembangunan Berkelanjutan, Lingkungan, Undang-Undang Nomor 32 Tahun 2009

\section{PENDAHULUAN}

Pada dasarnya pembangunan dengan lingkungan adalah dua hal yang sangat berbeda secara berlawanan (kontras). Pembangunan menuntut adanya perubahan yang lebih baik 
menuju kesejahteraan manusia, atau disebut pula dengan pertumbuhan. Salah satu sisi penting dari pembangunan adalah menuntut ketersediaan sumber-sumber alam. ${ }^{1}$ Sedangkan lingkungan, yang terdiri dari sumber daya alam dan ekosistem memiliki, selain sifatnya yang menuntut pelestarian fungsinya, juga memiliki sifat keterbatasan dalam ketersediaannya. Sifat lainnya adalah adanya sumber daya alam yang dapat diperbarui (renewable resources) seperti hutan atau hewan dan ada pula yang tidak dapat dibarui (unrenewable resources) seperti minyak dan gas bumi (migas), batu bara, besi dan barang tambang lain. ${ }^{2}$

Lingkungan sendiri didefinisikan kesatuan ruang dengan semua benda, daya, keadaan, dan makhluk hidup, termasuk manusia dan perilakunya, yang mempengaruhi alam itu sendiri, kelangsungan perikehidupan, dan kesejahteraan manusia serta makhluk hidup lainnya. ${ }^{3}$ Menurut Munajat Danusaputro lingkungan atau lingkungan hidup adalah semua benda dan daya serta kondisi, termasuk di dalamnya manusia dan tingkah perbuatannya, yang terdapat dalam ruang dimana manusia berada dan mempengaruhi kelangsungan hidup serta kesejahteraan manusia dan jasad-jasad hidup lainnya ${ }^{4}$. Sementara itu menurut Otto Soemarwoto lingkungan hidup

${ }^{1}$ N.H.T. Siahaan, Hukum Lingkungan, Pancuran Alam, Jakarta, 2008, hal.187

${ }^{2}$ Ibid, hal 187

${ }^{3}$ Undang-Undang Nomor 32 Tahun 2009 tentang Perlindungan dan Pengelolaan Lingkungan Hidup (UUPPLH) Pasal 1 ayat (1)

${ }^{4}$ Munajat Danusaputro, Buku Lingkungan, Buku I Umum, Binacipta, Jakarta, 1985, hal 67. Dikutip dari buku Muhammad Akib, Hukum Lingkungan Persfektif Global dan Nasional, Rajawali Pers, 2014, hal.1. diartikan sebagai ruang yang ditempati suatu makhluk hidup bersama dengan benda hidup dan tak hidup di dalamnya. Manusia bersama tumbuhan, hewan dan jasad renik menempati suatu ruang tertentu. Kecuali makhluk hidup dalam ruang itu terdapat juga benda tak hidup, seperti udara yang terdiri atas bermacam gas. Air dalam bentuk uap, cair dan padat, tanah dan batu. Ruang yang ditempati makhluk hidup bersama benda hidup dan tak hidup inilah dinamakan lingkungan hidup, ${ }^{5}$

Sedangkan pembangunan dapat kita artikan sebagai upaya sadar dan terencana dalam mengelola Sumber Daya Alam (SDA) untuk meningkatkan kesejahteraan dan mutu hidup masyarakat, dengan tetap menjaga keutuhan lingkungan. Pembangunan harus tetap dilaksanakan untuk mengatasi masalah-masalah lingkungan sebagai akibat keterbelakangan pembangunan dan kemiskinan penduduk, tetapi tidak merusak dan mencemarkan lingkungan, yang selanjutnya dikenal dengan kebijakan pembangunan yang berwawasan lingkungan (EcoDevelopment) atau kebijakan pembangunan yang berkelanjutan (Sustainable Development). ${ }^{6}$

Kebijakan tersebut (Sustainable Development) pertama kali dituangkan dalam Undang-Undang Lingkungan Hidup Nomor 4 Tahun $1982^{7}$ dengan istilah "pembangunan berwawasan

${ }^{5}$ Otto Soemarwoto, Ekologi, Lingkungan Hidup dan Pembangunan, Djambatan, Jakarta, 1991, hal. 48. Ibid, hal 1-2

${ }^{6} \mathrm{Ibid}$, hal 9

${ }^{7}$ Lihat lebih lanjut Undang-Undang Nomor 4 Tahun 1982 Tentang Ketentuan-Ketentuan Pokok Pengelolaan Lingkungan Hidup. 
AMDAL Sebagai Instrumen Dalam Mempertahankan Sustainable Development Yang Berwawasan Lingkungan

lingkungan “. Kemudian dalam Undang-Undang Pengelolaan Lingkungan Hidup Nomor 23 Tahun 1997 barulah digunakan istilah "pembangunan berwawasan lingkungan hidup". Selanjutnya dalam Undang-Undang Perlindungan dan Pengelolaan Lingkungan Hidup Nomor 32 Tahun 2009 menegaskan bahwa pembangunan berkelanjutan adalah upaya sadar dan terencana yang memadukan aspek lingkungan hidup, sosial, ekonomi ke dalam strategi pembangunan untuk menjamin keutuhan lingkungan hidup serta keselamatan, kemampuan, kesejahteraan dan mutu generasi kini dan generasi yang akan datang. ${ }^{9}$

Dengan hadirnya pembangunan maka timbul resiko lingkungan, yakni ancaman-ancaman yang membuat mutu lingkungan rusak, dan cadangannya menjadi tidak lestari. Tetapi pembangunan akan tetap jalan, karena jika tidak ada pembangunan maka tidak akan tercapai pertumbuhan dan kesejahteraan manusia. Maka disini perlu dicari jalan terbaik untuk mengurangi resiko dan kerugian-kerugiaan lingkungan, sehingga pembangunan dan lingkungan dapat berjalan dengan baik dalam suasana keserasian. Caranya ialah dari sejak dini melakukan perencanaan atas suatu kegiatan yang berkemungkinan yang dapat menimbulkan dampak besar dan penting terhdap lingkungan. Perencanaan demikian dengan menganalisis berbagai hal mulai dari

${ }^{8}$ Lihat Undang-Undang Nomor 23 Tahun 1997 Tentang Pengelolaan Lingkungan Hidup,

9 Baca lebih lanjut mengenai Pembangunan Berkelanjutan di Undang-Undang Nomor 32 Tahun 2009 Tentang Perlindungan dan Pengelolaan Lingkungan Hidup (UUPPLH) manfaat-manfaat kegiatan itu, dampak-dampak yang timbul terhadap lingkungan, sumber daya alam, kondisi alam, nilai-nilai sosial budaya, dan lain-lain. Melakukan perencanaan demikian dilakukan dengan Analisis Mengenai Dampak Lingkungan (AMDAL) $)^{10}$

AMDAL adalah salah satu dari sejumlah instrumen yang ditempuh untuk mencapai dan mempertahankan pembangunan berkelanjutan (Sustainable Development). Pembangunan berkelanjutan (Sustainable Development), disebut pula dengan pembangunan berkelanjutan yang berwawasan lingkungan. Konsep pembangunan berkelanjutan dapat kita lihat pada Pasal 1 ayat (3) Undang-Undang Perlindungan dan Pengelolaan lingkungan hidup yaitu UUPPLH Nomor 32 tahun 2009 yang menjelaskan bahwa "Pembangunan Berkelanjutan

(Sustainable Development) adalah upaya dan terencana yang memadukan aspek lingkungan hidup, sosial, dan ekonomi ke dalam strategi pembangunan untuk menjamin keutuhan lingkungan hidup serta keselamatam, kemampuan, kesejahteraan, dan mutu hidup generasi kini dan generasi masa depan. ${ }^{11}$

Adapun permasalahan yang penulis angkat dalam tulisan ini adalah:

1. Apa itu AMDAL dan bagaimana fungsi serta tujuannya?

2. Bagaiman peranan AMDAL dalam mempertahankan Sustainable

${ }^{10}$ N.H.T Siahaan, Op. Cit, 2008, hal 188-189

${ }^{11}$ Pasal 1 ayat (3) UUPPLH Nomor 32 Tahun 2009 
AMDAL Sebagai Instrumen Dalam Mempertahankan Sustainable

Development yang berwawasan
lingkungan?

Tujuan dari penulisan ini adalah:

Pertama, untuk mengkaji dan menganalisis lebih dalam mengenai Analisis Mengenai Dampak Lingkungan (AMDAL) serta bagaimana fungsi dan tujuannya berdasarkan Undang-Undang Perlindungan dan Pengelolaan Lingkungan Hidup (UUPPLH) Nomor 32Tahun 2009 serta Peraturan Pemerintah Nomor 27 Tahun 1999 tentang Analisis Mengenai Dampak Lingkungan (AMDAL).

Kedua, untuk menjelaskan sejauhmana peranan AMDAL dalam mempertahankan prinsip - prinsip Pembangunan Berkelanjutan (Sustainable Development) yang berwawasan lingkungan yang pada akhirnya Sustainable Development benar-benar dapat diwujudkan demi keberlangsungan hidup manusia masa kini dan masa yang akan datang.

Adapun Kegunaan dari penulisan ini adalah:

a. Dapat memberikan kontribusi tentang definisi AMDAL, fungsi, tujuan dan manfaat bagi mahasiswa, dosen, praktisi hukum serta pemerhati hukum khususnya hukum lingkungan.

b. Tulisan ini dapat mendorong penelitian lebih lanjut untuk lebih dapat mengembangkan kajian dan pengetahuan sejauhmana peranan AMDAl sebagai instrumen dalam mempertahankan Pembangaunan yang Berkelanjutan (Sustainable
Development) yang berwawasan lingkungan.

c. Dapat menambah kemampuan para sarjana hukum, praktisi hukum, akademisi hukum dan masyarakat umum dalam memahami masalah-masalah seputar AMDAL dan Sustainable Development (Pembangunan Berkelanjutan)

Dalam sistematika penulisan ini pertama, penulis akan memaparkan definisi AMDAL. Definsi ini terutama penulis ambil dari berbagai macam peraturan perundang-undangan yaitu UUPLH Nomor 23 Tahun 1997, UUPPLH Nomor 32 Tahun 2009 serta PP AMDAl Nomor 27 Tahun 1999 serta menguraikan definisi AMDAL dari berbagai pendapat pakar. Kedua, Penulis akan menjelaskan fungsi, tujuan dan manfaat AMDAL, ketiga, penulis akan menguraikan apa-apa saja Komponen AMDAL mulai dari Kerangka Acuan (KA), Analisis Dampak Lingkungan (ANDAL), Rencana Pengelolaan Lingkungan (RKL) dan Rencana Pemantauan Lingkungan (RPL), keempat, penulis akan mengkaji Komisi Penilai AMDAL, kelima, penulis menjelaskan macam-macam AMDAL dan terakhir keenam penulis akan menguraikan bagaimana mempertahankan Pembangunan Berkelanjutan (Sustainable Development).

Berdasarkan uraian di atas akhirnya penulis tertarik untuk mengkaji dan mendalami lebih dalam lagi mengenai AMDAL serta peranannya dalam mempertahankan Pembangunan Berkelanjutan 
AMDAL Sebagai Instrumen Dalam Mempertahankan Sustainable

Development Yang Berwawasan Lingkungan

(Sustainable Development) yang berwawasan lingkungan yang penulis anggap merupakan salah satu instrumen yang sangat penting demi terwujudnya keberlangsungan hidup generasi sekarang dan generasi masa depan. Akhirnya penulis tertarik untuk mengambil judul "AMDAL SEBAGAI INSTRUMEN DALAM MEMPERTAHANKAN

SUSTAINABLE DEVELOPMENT YANG BERWAWASAN

\section{LINGKUNGAN.}

\section{PERMASALAHAN}

Adapun permasalahan yang penulis angkat dalam tulisan ini adalah:

1. Apa itu AMDAL dan bagaimana fungsi serta tujuannya?

2. Bagaiman peranan AMDAL dalam mempertahankan Sustainable Development (Pembangunan yang Berkelanjutan) yang berwawasan lingkungan?

\section{PEMBAHASAN}

\section{A. PENGERTIAN AMDAL}

AMDAL pada dasarnya
berangkat dari pemikiran
mengenai pembangunan yang
berwawasan lingkungan atau
pembangunan berkelanjutan,
sebagaimana terdapat dalam
Konperensi Stockholm 1972
maupun KTT Rio 1992, malahan
KTT Rio menekankan bahwa
dalam hubungan itu perlu
ditempuh semacam peringatan
dini yang lebih populer dengan
Precautionary Principle. Prinsip 15

Deklarasi Rio yang
mengatakan:

"In order to protect the environment, the precautionary approach shall be widely applied by States according to their capabilities....."

Mengenai instrumen analisis dampak lingkungan, Prinsip 17 Deklarasi Rio mengatakan demikian: ${ }^{13}$

"Environment impact asssesment, as a national instrument, shall be undertaken for proposed activities that are likely to have a significant adverse impact on the environment and are subject to desicion of a competent national authority."

Munn, Pakar Amdal dari Canada memberikan definisi sebagai berikut:

"Amdal adalah suatu kegiatan (studi yang dilakukan untuk mengidentifikasi, memprediksi, menginterpretasi dan mengkomunikasikan pengaruh suatu rencana kegiatan itu pada lingkungan" (Penelitian Hukum Amdal 1994) ${ }^{14}$

Sedangkan dalam Hukum Lingkungan Amerika The National Environmental Policy Act of 1969" (NEPA 1969) dijelaskan:

"Enviromental Impact Assesment is asystematic process of identification, prediction, evaluation and presentation of the consequences of a proposed action at the stage in the decision making proces where serious

${ }^{12}$ N.H.T. Siahaan, 2008, Op.Cit, hal.190

${ }^{13} \mathrm{Ibid}$, hal.190

${ }^{14}$ Ibid, hal 190 
AMDAL Sebagai Instrumen Dalam Mempertahankan Sustainable

environmental damage can be avoid or minimize" (Penelitian Hukum Amdal 1994).

Uraian diatas telah dijelaskan bahwa membicarakan tentang Amdal tidak hanya menyangkut tentang masalah teknis semata tetapi juga menyangkut masalah administratif, ini dapat kita lihat dalam peraturan perundangundang Hukum Lingkungan di Indonesia yaitu: ${ }^{15}$

UUPLH Nomor 23 Tahun 1997 dalam Pasal 1 ayat memberikan pengertian Amdal sebagai berikut: ${ }^{16}$

"Analisis Mengenai Dampak Lingkungan adalah kajian mengenai dampak besar dan penting suatu usaha dan/atau kegiatan yang direncanakan pada lingkungan hidup, yang diperlukan bagi proses pengambilan keputusan tentang penyelenggaraan usaha dan/ atau kegiatan"

Sedangkan di UUPPLH Nomor 32 Tahun 2009 Pasal 1 ayat (11) mendefinisikan AMDAL sebagai berikut $^{17}$

"Analisis mengenai dampak lingkungan hidup yang selanjutnya Amdal, adalah kajian mengenai dampak penting suatu usaha dan/atau kegiatan yang direncanakan pada lingkungan hidup

15 Untuk memahami AMDAL secara peraturan perundang-undangan baca lebih lanjut Koesnadi HardjoSoemantri, Hukum Tata Lingkungan, Edisi VIII, Gadjah Mada University Press, Yogyakarta, 2012, hal. 252-268.

${ }^{16}$ Lihat lebih lanjut UUPLH Nomor 23 Tahun 1997

Pasal 1 ayat (21)

${ }^{17}$ Lihat UUPPLH Nomor 32 Tahun 2009 Pasal 1 ayat (11) yang diperlukan bagi proses pengambilan keputusan tentang penyelenggaraan usaha dan/atau kegiatan,"

AMDAL selain diatur dalam UUPLH Nomor 23 Tahun 1997 dan UUPPLH Nomor 32 Tahun 2009 juga diatur dalam Peraturan Pemerintah Nomor 27 Tahun 1999 Tentang Analisis Mengenai Dampak Lingkungan (AMDAl) dimana dikenal dengan istilah PP AMDAL. Di dalam Pasal 1 ayat (1) definisi mengenai AMDAL tidaklah jauh berbeda dengan UUPLH Nomor 23Tahun Tahun 1997 dan UUPPLH Nomor 32 Tahun 2009 dimana dalam PP AMDAL tersebut dijelaskan bahwa "Analisis mengenai dampak lingkungan hidup (AMDAL) adalah kajian mengenai dampak besar dan penting suatu usaha dan/atau kegiatan yang direncanakan pada lingkungan hidup yang diperlukam bagi proses pengambilan keputusan tentang penyelenggaraan usaha dan/atau kegiatan”. Dalam Pasal 2 PP AMDAL Nomor 27 Tahun 1999 dijelaskan pula:

(1) Analisis mengenai dampak lingkungan hidup merupakan bagian kegiatan studi kelayakan rencana usaha dan/ atau kegiatan.

(2) Hasil analisis mengenai dampak lingkungan hidup digunakan sebagai bahan perencanaan pembangunan wilayah.

(3) Penyusunan analisis mengenai dampak lingkungan hidup dapat dilakukan melalui pendekatan 
AMDAL Sebagai Instrumen Dalam Mempertahankan Sustainable

studi terhadap usaha dan/atau kegiatan tunggal, terpadu atau kegiatan kawasan.

Dalam Pasal 22 dan Pasal 23 Undang - Undang Nomor 32 Tahun 2009 tentang Perlindungan dan Pengelolaan Lingkungan Hidup di jelaskan:

Pasal 22. ${ }^{18}$

1. Setiap usaha dan/atau kegiatan yang berdampak penting terhadap lingkungan hidup wajib memiliki AMDAL.

2. Dampak penting ditentukan berdasarkan kriteria:

a. besarnya jumlah penduduk yang akan terkena dampak rencana usaha dan/atau kegiatan

b. luas wilayah penyebaran dampak

c. intensitas berlangsung, dan lamanya dampak

d. banyaknya komponen lingkungan lain yang akan terkena dampak; hidup

e. sifat kumulatif dampak

f. berbalik atau dan/atau tidak berbaliknya dampak

g. kriteria lain perkembangan ilmu teknologi, sesuai dengan pengetahuan dan teknologi

Pasal $23^{19}$

18 Lihat Pasal 22 Undang-Undang Nomor 32 Tahun 2009 tentang Perlindungan dan Pengelolaan Lingkungan Hidup (UUPPLH) kewajiban membuat AMDAL bagi setiap kegiatan dan usaha yang berdampak penting serta kriteria dampak penting tersebut.

19 Pasal 23 UUPLH Nomor 32 Tahun 2009 menjelaskan kriteria usaha dan/atau kegiatan yang
1. Kriteria usaha dan/atau kegiatan yang berdampak penting yang wajib dilengkapi dengan AMDAL terdiri atas:

a. pengubahan bentuk lahan dan bentang alam

b. eksploitasi sumber daya alam, baik yang terbarukan maupun yang tidak terbarukan

c. proses dan kegiatan yang secara potensial dapat menimbulkan

pencemaran dan/atau kerusakan lingkungan hidup serta pemborosan dan kemorosotan sumber daya alam dalam pemanfaatannya.

d. proses dan kegiatan yang hasilnya dapat mempengaruhi lingkungan alam, lingkungan buatan, serta lingkungan sosial dan budaya.

e. proses dan kegiatan yang hasilnya akan mempengaruhi

pelestarian kawasan konservasi sumber daya alam dan/atau perlindungan cagar budaya.

f. introduksi jenis tumbuhtumbuhan, hewan dan jasad renik

g. pembuatan dan penggunaan bahan hayati dan nonhayati

h. kegiatan yang mempunyai resiko tinggi dan /atau

berdampak penting yang wajib dilengkapi dengan AMDAL. 
AMDAL Sebagai Instrumen Dalam Mempertahankan Sustainable

mempengaruhi

pertahanan negara;

dan/atau

i. penerapan teknologi yang diperkirakan mempunyai potensi besar untuk mempengaruhi lingkungan hidup

2. Ketentuan lebih lanjut mengenai jenis usaha dan/atau kegiatan yang wajib dilengkapi dengan AMDAL sebagaimana yang dimaksud pada ayat (1) diatur dengan Peraturan Menteri.

\section{B. TUJUAN DAN FUNGSI}

\section{AMDAL}

Salah satu sistem hukum lingkungan yang paling mempengaruhi hukum lingkungan di Indonesia adalah sistem hukum lingkungan di Amerika Serikat. Amerika Serikat adalah negara yang pertama kalinya memperkenalkan "Analisis Mengenai Dampak Lingkungan" atau AMDAL sebagai salah satu instrumen penting dalam pengendalian dampak lingkungan. Hal ini tertuang dalam The National Environmental Policy Act of 1969" (NEPA 1969)20 sebagai sebuah aturan pengelolaan lingkungan pertama di dunia memiliki pengaruh ke sistem hukum

${ }^{20}$ Lihat lebih lanjut The National Environmental Policy Act of 1969 (NEFA 1969) pada section 102 (2) (c) yang menjelaskan setiap rencana kegiatan yang diperkirakan mempengaruhi kualitas lingkungan hidup manusia secara signifikan wajib memiliki AMDAL. lingkungan di berbagai belahan dunia dan tentu saja Indonesia. ${ }^{21}$

Sejak NEFA 1969 berlaku efektif pada tanggal 1 Januari 1970, maka perundang-undang lingkungan di negara lain pun berkembang. NEFA 1969 mengatur tentang Analisis Mengenai Dampak Lingkungan yang termuat pada Section 102 (2) (c) yaitu setiap rencana kegiatan yang diperkirakan mempengaruhi kualitas lingkungan hidup manusia secara signifikan wajib disertai Analisis Mengenai Dampak Lingkungan $\left(\right.$ AMDAL) ${ }^{22}$

Untuk memahami arti dan hakekat Undang-Undang Lingkungan Hidup 1969 Amerika Serikat, khususnya pelaksanaan AMDAL diberbagai negara, termasuk Indonesia dibawah ini digambarkan tujuan dan prosedur AMDAL.

Sewell mengidentifikasi 6 tujuan AMDAL yaitu: ${ }^{23}$

a. Sebagai tanggungjawab untuk generasi mendatang (responsibility to future generation)

b. Untuk menjamin lingkungan hidup yang berkualitas bagi seluruh rakyat Amerika (provision of a quality environment for all Americans)

${ }^{21}$ M. Daud Silalahi, AMDAL Dalam Sistem Hukum Lingkungan di Indonesia, PT. Suara Harapan Bangsa, Bandung, 2011, hal, 13

${ }^{22}$ Ibid, hal..13

${ }^{23}$ Ibid, hal.15 yang dikutip dari Granville H. Sewel, Environmental Qulity Management, Prentice-Hall, Inc, Englewood Cliffs, New Jersey, 1975. Baca juga bukunya Daud Silalahi, AMDAL Dalam Sistem Hukum Lingkungan Di Indonesia (Analisis Mengenai Dampak Lingkungan), Mandar Maju, Bandung, 1995, hal.14-15. 
AMDAL Sebagai Instrumen Dalam Mempertahankan Sustainable Development Yang Berwawasan Lingkungan

c. Upaya menghindari dampak lingkungan yang tidak diinginkan (prevention of undersirable impacts)

d. Upaya menjaga kelestarian warisan budaya nasional (preservation of national heritage)

e. Upaya untuk mencapai keseimbangam sumber daya menurut populasi (echievement of a population-resource balance)

f. Meningkatkan sumber daya terbaharui dan upaya daur ulang sumber daya tidak terbaharui (enhancement of renewable resources and recycling of non renewable ones)

Dalam konsep hukum baru ini setiap orang mempunyai hak untuk memperoleh lingkungan hidup yang baik dan sehat serta mempunyai kewajiban untuk memelihara (fundamental rights). NEFA-69 menyatakan bahwa proses AMDAL merupakan tanggung jawab yang dibebankan kepada pemerintah yang dilakukan melalui prosedur hukum berikut: ${ }^{24}$

a. Melakukan pendekatan sistemik dan lintas-sektor dalam perencanaan dan proses pembuatan kebijakan yang mempengaruhi lingkungan hidup.

b. Mengembangkan prosedur yang memasukan nilai-nilai lingkungan hidup yang tidak terukur. c. Menghindari konflik yang tidak menemukan penyelesaian mengenai penggunaan lahan, air maupun udara.

d. Melakukan kerjasama internasional untuk menjaga kualitas lingkungan hidup.

e. Membawa seluruh peraturan pelaksana into compliance dengan undang-undang.

\section{Adapun fungsi AMDAL} adalah: $:^{25}$

1. Fungsi AMDAL yang pertama sebagai bahan pertimbangan untuk perencanaan pembangunan suatu wilayah.

2. Fungsi AMDAl yang kedua untuk membantu dalam proses pengambilan keputusan atas kelayakan sebuah lingkungan hidup dari rencana usaha atau kegiatan tertentu.

3. Fungsi AMDAL yang ketiga adalah membantu memberikan masukan dalam rangka menyusun sebuah rancangan yang terperinci dari suatu rencana usaha atau kegiatan.

4. Fungsi AMDAL yang keempat membantu memberikan masukan dalam suatu proses penyusunan rencana pengelolaan dan pemantauan lingkungan hidup.

5. Fungsi AMDAL yang kelima membantu memberikan informasi terhadap masyarakat tentang dampak-dampak yang

${ }^{24}$ Ibid, hal. 15-16

25 www.pengertian pakar.com/2015/08/pengertianamdal-fungsi-amdal-dan-manfaat-amdal.html, Pengertian AMDAL, Fungsi AMDAL dan Manfaat $A M D A L$ diunduh pada tanggal 24 Nopember 2017 jam 12.30 WIB. Sumber: Buku dalam Penulisan Pengertian Amdal. Fungsi Amdal dan Manfaat Amdal. 
AMDAL Sebagai Instrumen Dalam Mempertahankan Sustainable

mungkin ditimbulkan dari suatu rencana usaha dan atau kegiatan.

6. Fungsi AMDAL selanjutnya adalah sebagai rekomendasi utama untuk sebuah izin usaha

7. Fungsi AMDAL berikutnya ialah Scientific Document dan Legal Document.

8. Fungsi AMDAL yang terakhir adalah izin kelayakan lingkungan.

Sedangkan manfaat AMDAL adalah sebagai berikut: ${ }^{26}$

1. Manfaat AMDAL untuk pemerintah

- AMDAL dapat membantu proses perencanaan untuk mencegah pencemaran dan kerusakan yang terjadi pada lingkungan.

- AMDAL dapat membantu mencegah konflik yang terjadi dengan masyarakat terhadap dampak kerusakan lingkungan yang ditimbulkan oleh kegiatan atau usaha.

- AMDAL dapat menjaga agar proses pembangunan berjalan sesuai dengan prinsip pembangunan yang berkelanjutan .

- AMDAL membantu mewujudkan pemerintahan yang bertanggungjawab dalam hal pengelolaan lingkungan hidup
2. Manfaat AMDAL untuk pemrakarsa atau pelaksana usaha

- AMDAL dapat membantu membuat usaha dan kegiatan menjadi lebih terjamin dan aman.

- AMDAL dapat dijadikan sebagai referensi untuk pengajuan kredit atau hutang usaha di bank

- AMDAL dapat dijadikan sarana dalam membatu interaksi dengan masyarakat sekitar sebagai bukti dari ketaatan terhadap hukum.

3. Manfaat AMDAL bagi Masyarakat

- AMDAL dapat menjelaskan kepada masyarakat mengenai dampak yang terjadi kedepannya setelah usaha atau kegiatan tersebut dijalankan.

- Dengan AMDAL masyarakat bisa ikut berpartisipasi dalam pelaksanaan suatu kegiatan dan mengontrol kegiatan tersebut.

- Dengan AMDAL masyarakat dapat ikut terlibat dalam proses pengambilan keputusan yang akan berpengaruh pada lingkungan tempat tinggalnya.

${ }^{26} \mathrm{Ibid}$. 
AMDAL Sebagai Instrumen Dalam Mempertahankan Sustainable

C. KOMPONEN-KOMPONEN DALAM AMDAL

AMDAL adalah keseluruhan
proses yang mempunyai
komponen: ${ }^{27}$

1. Kerangka Acuan bagi penyusunan ANDAL (KA) yaitu ruang lingkup studi analisis dampak lingkungan yang merupakan hasil pelingkupan (scoping)

Dalam teknis pengkajian AMDAL ada dikenal dengan Kerangka Acuan. (Kerangka Acuan (KA) adalah ruang lingkup kajian AMDAL sebagai hasil pelingkupan (scoping). Pelingkupan (scoping) adalah proses pemusatan kajian terhadap hal-hal yang berkaitan dengan dampak penting, yang bertujuan mengiidentifikasi sifat (the nature) dari konsekwensi dampak yang harus dipertimbangkan. ${ }^{28} \quad \mathrm{KA}$ merupakan pegangan penting merupakan dasar dalam rangka penyusunan Andal, yang berdasarkan hasil pelingkupan dapat diidentifikasi dampak-dampak yang mungkin timbul serta prakiraan lamanya dampak akan berlangsung. Prinsipnya KA yang baik dan dapat dipertanggungjawabkan secara ilmiah akan menghasilkan

${ }^{27}$ Mengenai Komponen-Komponen AMDAL lihat lebih lanjut, M. Daud Silalahi, Op.Cit, 2011.

28 D' Amore and Associates Lid: Study of Institutional Arrangements for Conducted SIA's, Ottawa Canada. 1986. Yang dikutip dari N.H.T.Siahaan Op.Cit, 2008, hal 203.
Andal, RKL dan RPL yang baik juga. ${ }^{29}$

\section{Analisis Dampak Lingkungan} (ANDAL) yang merupakan telaah cermat dan mendalam tentang dampak penting suatu rencana usaha atau kegiatan.

Mengenai ANDAL telah dijelaskan diatas, yakni sebagai telaahan yang cermat tentang dampak dari suatu rencana kegiatan. Pada dasarnya ANDAL bertujuan untuk mengidentifikasi suatu rencana kegiatan yang potensial berdampak lingkungan. Selain itu ANDAL di tujukan sebagai sarana mengidentifikasi rona lingkungan, memprakirakan dan mengevaluasi dampak penting. Manfaatnya ialah membantu pengambilan keputusan tentang kelayakan lingkungan dari berbagai kegiatan, serta sebagai pedoman untuk melaksanakan pengelolaan dan pemantauan. ${ }^{30}$

3. Rencana Pengelolaan Lingkungan (RKL) yaitu dokumen yang mengandung upaya penanganan dampak penting terhadap lingkungan hidup yang ditimbulkan.

4. Rencana Pemantauan Lingkungan (RPL) yaitu dokumen yang mengandung upaya pemantauan komponen yang terkena dampak penting

${ }^{29} \mathrm{Ibid}$, hal 203.

${ }^{30} \mathrm{Ibid}$, hal. 202 
AMDAL Sebagai Instrumen Dalam Mempertahankan Sustainable

akibat dari rencana usaha atau kegiatan.

Andal, RKL dan RPL, diajukan oleh pemrakarsa kepada Kepala Bapedal dan Gubernur melalui masingmasing komisi penilai pusat dan komisi penilai tingkat daerah. Kemudian instansi yang bertanggungjawab, yakni Bapedal menerbitkan keputusan kelayakan lingkungan suatu kegiatan berdasarkan hasil penilaian Andal, RKL dan RPL tersebut. Dalam waktu selambatnya 75 hari kerja sejak diterimanya dokumendokumen harus sudah diterbitkan keputusan kelayakan tersebut. Bilamana komisi penilai menyimpulkan bahwa dampak tidak dapat ditanggulangi oleh teknologi yang tersedia atau biaya penanggulangan dampak lebih besar daripada manfaat kegiatan tersebut, maka instansi bertanggungjawab memberikan keputusan berupa : kegiatan bersangkutan tidak layak lingkungan. ${ }^{31}$ Selanjutnya instansi yang berwenang dalam pemberian izin menolak pemberian izin bilamana dinyatakan bahwa kegiatan tidak layak lingkungan. ${ }^{32}$

Kapankah dokumen-dokumen AMDAL tersebut menjadi batal? Selanjutnya dokumen- dokumen AMDAl menjadi batal bila: ${ }^{33}$

1. Pemrakarsa mengubah halhal yang berkenaan dengan desain dan atau proses, kapasitas, bahan baku atau bahan penolong. Terhadap masalah demikian, pemrakarsa wajib membuat AMDAL baru.

2. Terjadi perubahan lingkungan secara sangat mendasar akibat bencana alam atau akibat lain pada waktu:

- sebelum waktu kegiatan dilaksanakan

- pada waktu kegiatan dilaksanakan.

Pemrakarsa yang mengalami hal diatas wajib membuat AMDAL baru.

\section{KOMISI PENILAI AMDAL}

Mengenai Komisi Penilai Amdal diatur dalam Pasal 29, 30 dan 31 Undang-Undang Nomor 32 Tahun 2009: ${ }^{34}$

Pasal 29

(1)Dokumen Amdal dinilai oleh Komisi Penilai Amdal yang dibantu oleh Menteri, Gubernur, atau Bupati /Walikota sesuai dengan kewengannya.

${ }^{31}$ Pasal 22 PP No.27 Tahun 1999 Tentang Analisis

Mengenai Dampak Lingkungan (AMDAL)

${ }^{33}$ Ibid, 205

${ }^{34}$ Lihat lebih lanjut Pasal 29, 30 dan 31 UUPPLH

Nomor 32 Tahun 2009 yang membahas tentang Komisi

${ }^{32}$ N.H.T. Siahaan, Op.Cit, 2008, hal.204. 
AMDAL Sebagai Instrumen Dalam Mempertahankan Sustainable

(2)Komisi Penilai Amdal wajib memiliki lisensi dari Menteri. Gubernur, atau Bupati /Walikota sesuai dengan kewenagannya.

(3)Persyaratan dan tatacara lisensi sebagaimana yang dimaksud dalam ayat (2) diatur dengan Peraturan Menteri.

Pasal 30

(1)Keanggotaan Komisi Penilai Amdal sebagaimana yang dimaksud dalam Pasal 29 terdiri atas wakil dari unsur :

a. Instansi lingkungan hidup

b. instansi teknis terkait

c. Pakar dibidang pengetahuan yang terkait dengan jenis usaha dan /atau kegiatan yang sedang dikaji

d. Pakar dibidang pengetahuan yang terkait dengan dampak yang timbul dari suatu usaha dan/atau kegiatan yang sedang dikaji

e. Wakil dari masyarakat yang berpotensi terkena dampak; dan

f. Organisasi Lingkungan Hidup

(2)Dalam melaksankan tugasnya, Komisi Penilai Amdal dibantu oleh tim teknis yang terdiri atas pakar independen yang melakukan kajian teknis dan sekretariat yang dibentuk untuk itu.

(3) Pakar independen dan sekretariat sebagaimna yang dimaksud dalam ayat (3)

ditetapkan oleh Menteri,

Gubernur, atau Bupati

/Walikota sesuai dengan kewenangannya.

\section{Pasal 31}

Berdasarkan hasil Penilaian Komisi Amdal, Menteri, Gubernur, atau Bupati/Walikota menetapkan keputusan kelayakan atau ketidaklayakan lingkungan hidup sesuai dengan kewenangannya.

\section{PROSEDUR PELAKSANAAN AMDAL MENURUT PP NOMOR 27 TAHUN 1999}

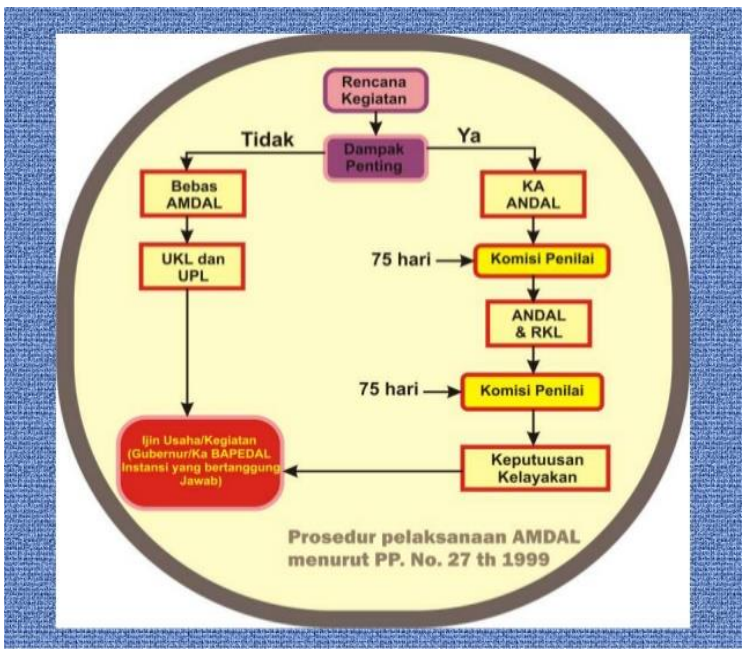

Sumber:

https://www.google.com/search?q=prosedur+ pengajuan+amdal\&source $=1 \mathrm{nms} \&$ tbm $=$ isch $\& s$ $\mathrm{a}=\mathrm{X} \& \mathrm{ved}=0$ ahUKEwiZoP29m_bZAhVMLY8 KHewMBCoQ AUICygC\&biw $=1366 \& b i h=6$ $54 \#$ imgrc $=$

\section{E. MACAM-MACAM AMDAL}

Apabila dilihat dari peraturan dan berbagai keputusan administratif mengenai ke-amdalan maka sistem AMDAL dapat digolongkan ke dalam beberapa 
jenis. Penggolongan demikian dilakukan melalui pendekatan kajian terhadap jenis-jenis kegiatan. ${ }^{35}$ Jenis-jenis AMDAL tersebut adalah sebagai berikut: a. Amdal secara Tunggal, b.Amdal Sektor atau Sektoral, c. Amdal Terpadu atau Multi Sektor, d. Amdal Regional atau disebut juga Amdal kegiatan Kawasan, e. Amdal yang beraspek Sosial. ${ }^{36}$

\section{AMDAL secara Tunggal}

AMDAL ini dilakukan terhadap satu jenis usaha atau kegiatan, karena kegiatannya bersifat tunggal maka kewenangan pembinaannya berada di bawah satu instansi yang membidangi usaha atau kegiatan tersebut.

\section{AMDAL Sektor}

Amdal secara Tunggal di atas dapat juga disebut sebagai Amdal Sektor, atau Amdal Sektoral, karena kebijakan tentang penetapan kewajiban Amdalnya ditetapkan oleh Menteri sektoral Pasal 3 ayat (2) PP Amdal $1999^{37}$ mengatakan bahwa jenis usaha atau kegiatan yang wajib memiliki Amdal ditetapkan Menteri setelah mendengar dan

35 Pasal 2 ayat (3) PP Nomor 27 Tahun 1997 mengatakan; "Penyusunan Analisis Mengenai Dampak Lingkungan Hidup dapat dilakukan melalui pendekatan studi terhadap usaha dan/atau kegiatan tunggal, terpadu atau kegiatan dalam kawasan”. Bila disimak, ketentuan ini hanya menggolongkan 3 jenis Amdal, akan tetapi jika disimpulkan dari berbagai keputusan pemerintah, khususnya Menteri Negara Lingkungan Hidup/Kepala Bapedal, diluar tiga jenis demikian dapat digolongkan lagi sebagai jenis Amdal. Misalnya Amdal yang dalam penyusunannya memasukan aspek-aspek/kajian-kajian sosial.

${ }^{36}$ N.H.T. Siahaan, Op.Cit, 2008, hal. 210-213

${ }^{37}$ Lihat lebih lanjut PP Amdal Nomor 27Tahun 1999

Pasal 3 ayat (2). memperhatikan saran dan pendapat Menteri lain atau pimpinan LPND (Lembaga Pemerintah Non Departemen) terkait. Dengan demikian, mengenai kewajiban Amdal atas suatu kegiatan, sifatnya sektoral.

\section{AMDAL Terpadu atau AMDAL Multisektor}

Amdal jenis ini adalah hasil kajian mengenai dampak besar dan penting usaha atau kegiatan bersifat terpadu, yang direncanakan terhadap lingkungan. Amdal ini terhadap dalam satu kesatuan hamparan ekosistem yang melibatkan kewenangan lebih dari satu instansi yang membidangi kegiatan tersebut.

Kriteria Amdal terpadu demikian meliputi: a. berbagai kegiatan tersebut mempunyai keterikatan dilihat dari proses perencanaan, pengelolaan dan proses produksinya, $b$. jenis-jenis usaha atau kegiatan yang amdalnya menjadi kewenangan berbagai instansi teknis yang membidanginya, c. kegiatan tersebut berada dalam kesatuan hamparan ekosistem (dalam satu kesatuan ekosistem yang sama), d. kegiatan tersebut berada di bawah satu pengelolaan atau lebih.

\section{AMDAL Sosial}

Amdal ini sebenarnya pada dasarnya sama dengan jenis Amdal yang disebut di atas. Namun karena aspek-aspek sosial dimasukan sebagai bagian 
terpadu dan sistem kajiannya juga berbeda dengan kajian teknis Amdal yang lain. Maka dapat digolongkan sebagai jenis Amdal tersendiri.

Di negara kita, kecendrungankecendrungan yang timbul tidak jarang menjadi sumber keresahan sosial atau konflik horisontal dan vertikal, yakni antara pemrakarsa /pemilik proyek kegiatan dengan penduduk masyarakat sekitar, antara masyarakat-LSM dengan pemerintah, pengambil keputusan. Faktornya adalah gangguan lingkungan (enviromental harm), polusi, penggunaan sumber daya alam tanpa kearifan, penambangan hutan di kawasan lindung atau eksploitasi hutan (illegal logging) oleh kaum kapitalis. Gangguan lain berupa dimutasikannya penduduk sekitar, atau situasi lingkungan kerja penduduknya tadi berubah. Disamping itu, kecuali memunculkan dampakdampak bersifat fisik, muncul juga persoalan-persoalan dalam versi interrelationship. Bentukbentuk persoalan sosial adalah timbulnya kesenjangan sosial (social gap) di antara komunitas penduduk. Misalnya antara komunitas penduduk pemukiman yang terencana (planned settlement), baik dalam tipe pemukiman mewah, tipe semi elit, tipe sedang, BTN, hingga tipe perumnas, disatu pihak dengan komunitas penduduk pemukiman asli atau alamiah yang biasa disebut dengan pemukiman kampung di pihak lain. Gaya hidup pemukiman plannned settlement sangat berbeda dengan masyarakat yang berada di lingkungan komunitas kampung sekitarnya. Kondisi ini menimbulkan keberbedaan (social gap). Bahkan tidak jarang membawa pengaruh disharmoni kepada lingkungan penduduk sekitar.

\section{F. MEMPERTAHANKAN SUSTAINABLE DEVELOPMENT (PEMBANGUNAN BERKELANJUTAN).}

Masalah lingkungan tanpa menyinggung konsep pembangunan berkelanjutan (Sustainable Development) dalam era pembangunan menjelang abad ke-21 dirasakan kurang lengkap. Bahkan, kelompok ahli dalam Komisi PBB tentang Lingkungan dan Pembangunan telah meletakkan prinsip-prinsip hukum lingkungan yang akan mendukung pembangunan ekonomi dunia pada saat ini hingga menjelang berakhirnya abad ke-20. ${ }^{38}$

Pembangunan berkelanjutan (ada yang menyebutkan pembangunan terlanjutkan) satu sisi dari mata uang yang sama dengan istilah pembangunan yang berwawasan lingkungan sebagaimana dimuat dalam Pasal 1, butir 13 UULH-82 (diperbaharui tahun 1997). Untuk memahami hubungan kedua istilah tersebut, di bawah ini

${ }^{38}$ M Daud Silalahi dan Kristianto, Hukum Lingkungan Dalam Perkembangannya Di Indonesia, KENI, Bandung, hal. 202. 
AMDAL Sebagai Instrumen Dalam Mempertahankan Sustainable

diberikan batasan dan deskripsi umum yang menerangkan makna kedua istilah tersebut. Pembangunan berwawasan lingkungan atau ecodevelopment adalah: ${ }^{39}$

"Upaya sadar dan berencana menggunakan dan mengelola sumber daya secara bijaksana dalam pembangunan yang berkesinabungan untuk meningkatkan mutu hidup". Penjelasan ketentuan di atas menguraikan bahwa:

"penggunaan dan pengelolaan sumber daya secara bijaksana berarti senantiasa memperhitungkan dampak kegiatan tersebut terhadap lingkungan serta kemampuan sumber daya untuk menopang pembangunan secara berkesinambungan"

Sedangkan, pembangunan berkelanjutan atau Sustainable Development diuraikan oleh Komisi PBB tentang Lingkungan dan Pembangunan sebagai berikut: ${ }^{40}$

"to ensure that it meets the needs of the present without compromising the ability of future generations to meet their own needs. The concept of sustainable development does imply limits not absolute limits but limitations imposed by the present state of technology and social organization on environmental resources and by the ability of the biosphere to absorbe the effect of human activities. But technology and social organization can be both managed and improved to make way for a new era of economic growth."

${ }^{39}$ Ibid, hal. 202

${ }^{40}$ Ibid, hal. 202-203.
UUPPLH Nomor 32 Tahun 2009 pasal 1 ayat (3) mendefinisikan Pembangunan Berkelanjutan atau Sustainable Development adalah: "upaya sadar dan terencana yang memadukan aspek lingkungan hidup, sosial, ekonomi ke dalam strategi pembangunan untuk menjamin keutuhan lingkungan hidup serta keselamatan, kemampuan, kesejahteraan, dan mutu hidup generasi masa kini dan generasi masa depan". ${ }^{41}$

Sebelumnya pada UndangUndang 23 Tahun 1997 tentang Pengelolaan Lingkungan Hidup Pasal 1 ayat (3) juga telah diberikan definisi Sustainable Development (Pembangunan Berkelanjutan sebagai berikut “ Pembangunan Berkelanjutan yang berwawasan lingkungan hidup adalah upaya sadar dan terencana, yang memadukan lingkungan hidup, termasuk sumber daya, ke dalam proses pembangunan untuk menjamin kemampuan, kesejahteraan dan mutu hidup generasi masa kini dan generasi masa depan $^{\prime 42}$

Pembangunan selalu membawa perubahan dan dampak, positif maupun negatif. Dampak positif merupakan salah satu tujuan dari dilaksanakannya pembangunan, yaitu perubahan positif bagi manusia dalam mencapai kesejahteraannya. Konsep Pembangunan Berkelanjutan muncul karena selama ini, tidak

\footnotetext{
${ }^{41}$ Lihat Pasal 1 ayat (3) UUUPPLH Nomor 32 Tahun 2009 memberikan definisi tentang Sustanable Development.

${ }^{42}$ Pasal 1 ayat (3) Undang-Undang Nomor 23 Tahun 1997 Tentang Pengelolaan Lingkungan Hidup.
} 
saja di Indonesia, tetapi juga di seluruh dunia, terutama di negara berkembang, pembangunan kurang mempertimbangkan aspek atau dampak negatifnya terhadap lingkungan, baik aspek hayati (kerusakan ekosistem dan punahnya keanekaragaman hayati) maupun nonhayati (sosial budaya). Sebelum konsep Pembangunan Berkelanjutan (Sustainable Deveploment) dicanangkan, pembangunan didominasi oleh pertimbangan ekonomi, hampir tanpa mempertimbangkan dampak negatifnya terhadap lingkungan. ${ }^{43}$

Konferensi Stockholm $1972^{44}$ yang membahas lingkungan hidup dan telah menyepakati 26 prinsip pengelolaan lingkungan yang dikenal dengan Deklarasi Stockholm secara implisit sudah mengumandangkan konsep pembangunan berkelanjutan bagi semua negara di dunia. Prinsip Sustainable Development mulai menarik perhatian untuk dibahas lebih lanjut. Karena waktu pelaksanaan konferensi PBB ini merupakan tonggak atau sejarah keprihatinan bangsa-bangsa terhadap lingkungan hidup, maka

43 Marhaeni Ria Siambo, Hukum Lingkungan Dan Pelaksanaan Pembangunan Berkelanjutan Di Indonesia, Gramedia Pustaka Utama, Jakarta, 2012, hal. 57-58.

44 Konferensi PBB tentang lingkungan hidup diselenggarakan pada tanggal 5-16 Juni di Stockholm, Swedia, literatur hukum lingkungan umumnya merujuk Konferensi Stockholm sebagai cikal bakal dari tumbuh dan perkembangan hukum lingkungan internasional maupun nasional karena konferensi ini menghasilkan sebuah dokumen, yaitu: Deklarasi tentang Lingkungan Hidup Manusia yang juga disebut sebagai Deklarasi Stockholm yang dianggap sebagai sumber bagi pembangunan hukum lingkungan. Lihat buku Takdir Rahmadi, Hukum Lingkungan Di Indonesia, Rajawali Pers, 2015, hal.8-9. tanggal pelaksanaan Konferensi Stockholm, yaitu 5 Juni, dijadikan sebagai Hari Lingkungan Hidup Sedunia. ${ }^{45}$

Aspek lingkungan merupakan masalah yang kait-mengait dengan pembangunan sehingga tidak dapat dilihat sebagai sektor yang berdiri sendiri, kemudian dipertentangkan dengan pembangunan, seolah-olah kita diperhadapkan pada pilihan antara lingkungan disatu pihak dan pembangunan dipihak lain. Belum terjadinya sinergi antara lingkungan dan pembangunan adalah bentuk keprihatinan terhadap rendahnya kemampuan lingkungan untuk menopang pembangunan secara berkelanjutan. Apabila pembangunan dilihat cara pandang sektoral, tanpa mengaitkannya dengan dengan faktor-faktor lain terus berlangsung, maka kelangsungan pembangunan akan terancam. ${ }^{46}$

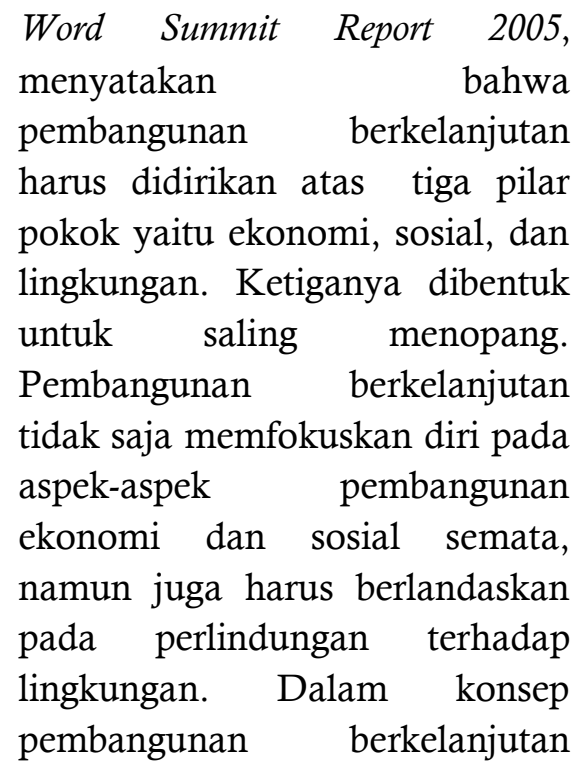

${ }^{45}$ Marhaeni Ria Siombo, Op,Cit, 2012, hal.58.

${ }^{46}$ Ibid, hal. 58 
AMDAL Sebagai Instrumen Dalam Mempertahankan Sustainable

Development Yang Berwawasan Lingkungan

termasuk juga syarat terpenuhinya kebutuhan dasar (basic needs) dan terbukanya kesempatan untuk mendapatkan kehidupan yang lebih baik. ${ }^{47}$

Prinsip Pembangunan Berkelanjutan mengacu pada pembangunan yang meliputi pembangunan sosial, ekonomi dan lingkungan yang baik. Prinsip-prinsip yang terkandung dalam konsep pembangunan berkelanjutan dikemukakan secara rinci dalam deklarasi dan perjanjian internasional yang dihasilkan melalui konferensi PBB tentang lingkungan dan pembangunan (United Nations Conference on Environment and Development) di Rio de Janerio pada tahun 1992. Dari berbagai dokumen yang dihasilkan pada konferensi itu, secara formal terdapat lima prinsip utama pembangunan berkelanjutan, yaitu: ${ }^{48}$

1. Prinsip

Keadilan

Antargenerasi (Intergenerational Equity Principle). Prinsip ini mengandung makna bahwa setiap generasi umat manusia di dunia ini memiliki hak untuk menerima dan menempati bumi, bukan dalam kondisi yang buruk akibat perbuatan generasi sebelumnya.

2. Prinsip keadilan dalam satu generasi (Intergenerational Equity Principle). Prinsip ini merupakan prinsip yang

${ }^{47} \mathrm{Ibid}$, hal.60-61

48 Ibid , hal 62-63.

4. Prinsip Perlindungan

Keragaman Hayati. Prinsip ini merupakan prasyarat dan berhasil tidaknya pelaksanaan prinsip keadilan antargenerasi. Perlindungan keragaman hayati diperlukan demi pencegahan dini.

5. Prinsip Internalisasi Biaya Lingkungan. Kerusakan lingkungan dapat dilihat sebagai external cost dari suatu kegiatan ekonomi yang diderita oleh pihak yang tidak terlibat dalam kegiatan ekonomi tersebut. Jadi, kerusakan lingkungan merupakan external cost yang harus ditanggung oleh pelaku ekonomi. Oleh karena itu, biaya kerusakan lingkungan harus di integrasikan ke dalam proses pengambilan keputusan 
AMDAL Sebagai Instrumen Dalam Mempertahankan Sustainable

Development Yang Berwawasan Lingkungan

yang berkaitan dengan

penggunaan sumber-sumber

alam tertentu.

Dari uraian diatas kita dapat mengambil kesimpulan bahwa sebenarnya tujuan Pembangunan Berkelanjutan (Sustainable Development) adalah: ${ }^{49}$

\begin{tabular}{lrr} 
Implementasi & konsep \\
pembangunan & \multicolumn{2}{r}{ berkelanjutan } \\
harus bisa & mempertemukan \\
paling tidak & tiga tujuan \\
pembangunan, & yaitu tujuan
\end{tabular} ekonomi, tujuan sosial, tujuan ekologi. Tujuan ekonomi adalah menciptakan pertumbuhan, pemerataan dan efisiensi. Sedangkan tujuan sosial adalah pemberdayaan, partisipasi, mobilitas sosial, kohesi sosial dan identitas budaya. Dan yang terakhir adalah tujuan ekologi menciptakan keutuhan ekosistem, daya dukung, keanekaragaman hayati serta lingkungan global.

Dari uraian diatas jelas sekali bahwa paradigma pembangunan berwawasan lingkungan dan berkelanjutan tidak boleh mempertentangkan ketiga tujuan tersebut, melainkan harus mensinergikan satu satu yang lain dalam setiap kegiatan pembangunan. Tujuan pembangunan dari aspek ekonomi memang diperlukan untuk meningkatkan pertumbuhan, tetapi kalau tidak hati-hati dapat mengakibatkan kerusakan ekosistem dan daya dukung lingkungan. Kerusakan ekosistem dan daya dukung

${ }^{49}$ Muhammad Akib, Op.Cit, 2014, hal. lingkungan tentu akan

berdampak negatif seperti arus balik (feed back) terhadap pembangunan ekonomi, yang pada akhirnya juga akan sangat mempengaruhi tujuan sosial seperti pemberdayaan, partisipasi, mobilisasi sosial, dan lain sebagainya. Sebaliknya, pembangunan ekologi dapat merupakan dari pembangunan sosial. Kondisi lingkungan dan SDA yang baik merupakan modal besar untuk mendukung keberhasilan pembangunan di bidang ekonomi, dan dengan sendirinya akan membawa dampak positif pada aspek kesejahteraan masyarakat (tujuan sosial).

AMDAL merupakan salah satu instrumen untuk mencapai tujuan dari Sustainable Development tersebut. Dengan AMDAL sebuah kegiatan atau usaha yang ada pengaruhnya terhadap lingkungan akan lebih berhatihati terlebih dahulu ketika akan melakukan kegiatan atau usaha tersebut. Jika tidak ada AMDAL, maka tiga tujuan Sustainable Development tersebut baik tujuan ekonomi, tujuan sosial maupun tujuan ekologi tidak akan terwujud. Bahkan akan membahayakan keberadaan generasi sekarang maupun generasi masa depan.

\section{PENUTUP.}

Dalam bagian penutup penulis mencoba memberikan kesimpulan dari penulisan ini. Kesimpulan merupakan jawaban dari dua rumusan masalah diatas. 
AMDAL Sebagai Instrumen Dalam Mempertahankan Sustainable

Adapun kesimpulan penulis adalah:

AMDAL (Analisis Mengenai Dampak Lingkungan Hidup) adalah kajian mengenai dampak penting suatu usaha dan/atau kegiatan yang direncanakan pada lingkungan hidup yang diperlukan bagi proses pengambilan keputusan tentang penyelenggaraan usaha dan/atau kegiatan. (UUPPLH Nomor 32 Tahun 2009 Pasal 1 ayat (11)

Di dalam Pasal 1 ayat (1) Peraturan Pemerintah Nomor 27 Tahun 1999 tentang AMDAL dijelaskan bahwa AMDAL (Analisis Mengenai Dampak Lingkungan Hidup) adalah kajian mengenai dampak besar dan penting suatu usaha dan/atau kegiatan yang direncanakan pada lingkungan hidup yang diperlukam bagi proses pengambilan keputusan tentang penyelenggaraan usaha dan/atau kegiatan.

Dalam Pasal 2 PP AMDAL Nomor 27 Tahun 1999 dijelaskan pula:

(1)Analisis mengenai dampak lingkungan hidup merupakan bagian kegiatan studi kelayakan rencana usaha dan/ atau kegiatan.

(2)Hasil Analisis Mengenai Dampak Lingkungan Hidup digunakan sebagai bahan perencanaan pembangunan wilayah.
(3)Penyusunan
Analisis Mengenai
Dampak

Lingkungan Hidup dapat dilakukan melalui pendekatan studi terhadap usaha dan/atau kegiatan tunggal, terpadu atau kegiatan kawasan.

UUPPLH Nomor 32 Tahun 2009 pasal 1 ayat (3) mendifinisikan Pembangunan Berkelanjutan atau Sustainable Development adalah: Upaya sadar dan terencana yang memadukan aspek lingkungan hidup, sosial, ekonomi ke dalam strategi pembangunan untuk menjamin keutuhan lingkungan hidup serta keselamatan, kemampuan, kesejahteraan, dan mutu hidup generasi masa kini dan generasi masa depan.

AMDAL disebut sebagai sarana untuk mempertahankan Sustainable Development karena, pertama, AMDAL dapat menjaga agar proses pembangunan berjalan sesuai dengan prinsip Pembangunan Berkelanjutan (Sustainable Development), kedua, AMDAL mampu membantu proses perencanaan untuk mencegah pencemaran lingkungan sehingga dengan demikian Sustainable Development dapat dipertahankan, ketiga, AMDA1 sebagai bahan informasi bagi masyrakat tentang dampakdampak yang mungkin timbul dari suatu rencana usaha dan kegiatan, keempat AMDAL bisa menjadi suatu bahan pertimbangan untuk melakukan suatu 
AMDAL Sebagai Instrumen Dalam Mempertahankan Sustainable

pembangunan suatu wilayah dengan prinsip Sustainable Development yang berwawasan lingkungan dan yang terakhir yang kelima, AMDAL dapat menjelaskan kepada masyarakat mengenai dampak yang terjadi ke depannya setelah usaha atau kegiatan tersebut dilaksanakan sehingga AMDAL dapat menjaga lingkungan dari kerusakan dan pencemaran. Berdasarkan uraian ini sangat tepatlah kita mengatakan bahwa AMDAL merupakan salah satu instrumen untuk mempertahankan

Pembangunan Berkelanjutan (Sustainable Development) yang berwawasan lingkungan.

\section{DAFTAR PUSTAKA}

Akib, Muhammad, Hukum Lingkungan Persfektif Global dan Nasional, Rajawali Pers, Jakarta, 2014

Hardjosoemantri, Koesnadi, Hukum Tata Lingkungan, Edisi VIII, Gadjah Mada University Press, Yogyakarta, 2012

Rahmadi, Takdir, Hukum Lingkungan Di Indonesia, Edisi Kedua, Rajawali Pers, Jakarta, 2015.

Siahaan, N.H.T, Hukum Lingkungan, Pancuran Alam, Jakarta, 2008.

Silalahi, Daud, AMDAL Dalam Sistem Hukum Lingkungan Di Indonesia (Analisis Mengenai Dampak Lingkungan), Mandar Maju, Bandung, 1995.
Silalahi, Daud, AMDAL Dalam Sistem Hukum Lingkungan Di Indonesia, PT Suara Harapan Bangsa, Bandung, 2011.

Silalahi, Daud, Kristianto, Hukum Lingkungan Dalam Perkembangan Di Indonesia, KENI, Bandung, 2015.

Siombo, Marhaeni Ria, Hukum Lingkungan Dan Pelaksanaan Pembangunan Berkelanjutan, Gramedia Pustaka Utama, Jakarta, 2012.

Undang-Undang Nomor 4 Tahun 1982 Tentang Ketentuan-Ketentuan Pokok Pengelolaan Lingkungan Hidup.

Undang-Undang Nomor Nomor 23 Tahun 1997 Tentang Pengelolaan Lingkungan Hidup

Undang-Undang Nomor 32 Tahun 2009 Tentang Perlindungan dan Pengelolaan Lingkungan Hidup.

Peraturan Pemerintah Nomor 27 Tahun 1999 Tentang Analisis Mengenai Dampak Lingkungan (AMDAL).

The National Enviromental Policy Act 1969 (NEFA 1969)

\section{www.pengertian}

pakar.com/2015/08/pengertian-amdalfungsi-amdal-dan-manfaat-amdal.html, pengertian Amdal, fungsi Amdal dan Manfaat Amdal.

https://www.google.com/search?q=prose dur+pengajuan + amdal $\&$ source $=\operatorname{lnms} \&$ tb $\mathrm{m}=$ isch\&sa $=$ X\&ved=0ahUKEwiZoP29m bZAhVMLY8KHewMBCoQAUICygC\& biw $=1366 \& b i h=654 \#$ imgrc $=$ 